УДК 343.85:343.34

DOI https: / / doi.org/10.32837/yuv.v0i4.979

\title{
Н. Федчун,
}

кандидат юридичних наук, доцент

кафедри кримінології та кримінально-виконавчого права

Національного університету «Одеська юридична академія»

\section{ОСНОВИ ПРОФІЛАКТИКИ ЗЛОЧИНІВ, ЩО ВЧИНЯЮТЬСЯ ПРИ ПОРУШЕННІ ПРАВИЛ БЕЗПЕКИ}

Протягом тривалого часу проблеми необережної злочинності в кримінології були другорядними, оскільки існувала думка про незначну суспільну небезпечність злочинів цього виду. Така позиція є хибною. За розміром і характером заподіюваної шкоди злочини, скоєні з необережності, значно переважають умисні злочини, які зазвичай активно вивчаються. Практика свідчить, що при порушенні правил безпеки, необережні злочини становлять абсолютну більшість.

Як правило, у випадку злочинної необережності характер завданого збитку визначають, не стільки ступенем «моральної зіпсованості» особи, скільки сферою діяльності суб'єкта, способом використання ним знарядь і засобів, ситуацій, за яких скоєно злочин, а також багатьма іншими обставинами, що можуть бути випадковими для суб'єкта. Тому в необережних злочинах наявне певне протиріччя між соціально-психологічною характеристикою правопорушника і значущістю наслідків, що настають.

Активна технізація усіх сфер людського життя, збільшення кількості джерел підвищеної небезпеки та ускладненням вимог до осіб, які їх (джерела) експлуатують, обумовлюють необхідність актуалізації досліджень проблеми профілактики злочинів, що вчиняються при порушенні правил безпеки.

До прикладу, не оцінити збитки, спричинені аваріями на промислових об’єктах, різного роду техногенними катастрофами, забруднення довкілля, дорожньо-транспортні пригоди, пожежі тощо. Рівень аварійності, який би він не був, вимагає невпинної уваги, особливо в галузях, пов'язаних з ризиками глобальних наслідків.

До питань необережної злочинності неодноразово звертались в своїх працях такі вчені як Антонян Ю.М., Бузало П.М., Василевич В.В., Дагель П.С., Даньшин I.M., Джужа O.M., Дрішлюк І.А., Закалюк А.П., Зелінський А.Ф., Іншаков С.М., Крайник Г.С., Мисливий В.А., Нежурбіда С.I. та ін.

Так, в літературі зазначається, що в основі індивідуальної злочинної поведінки, зокрема й необережної, у причинній площині лежать як ситуація, так і негативні психологічні деформаціï, що прийняли форму антисуспільної установки особистості. Зовнішні фактори діють опосередковано, через риси характеру, вольові й емоційні якості, ціннісно-нормативні характеристики свідомості, мотиваційну сферу та сферу потреб.[1, С.66] Умовою переходу зовнішніх факторів у внутрішні $€$ різноманітні форми діяльності людини, кожна з яких відображається у внутрішньому світі людини.

Так, порушуючи встановлені правила безпеки експлуатації або ремонту, особи-працівники транспорту або виробництва діють на шкоду соціальному зв'язку, змінюючи характер своєї діяльності таким чином, що вона стає небезпечною для суспільства. У поєд- 


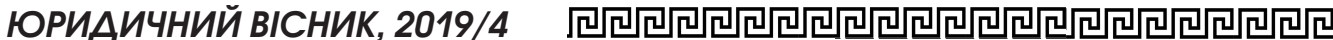

нанні із зовнішніми умовами (погодні умови, особливості технічного засобу і т.п.) це призводить до втрати контролю над транспортним засобом або його механізмами, які забезпечують його нормальне функціонування. Особа ж винного в порушенні правил безпеки характеризується антисоціальною установкою, що виражається в зневажливому ставленні до безпеки на транспорті або виробництві, до життя і здоров'я людей, або недостатньо вираженою соціальною установкою, тобто недостатньо дбайливим ставленням до зазначених соціальних цінностей.

Безумовно, конкретна ситуація помітно впливає на порушення правил безпеки, певним чином впливаючи на порушника. Однак, характер зазначеного впливу не завжди однозначний: конкретна ситуація може не тільки сприяти створенню загрози безпеки, а й бути індиферентною або навіть ускладнювати реалізацію загрози.

Так, відносну більшість всіх аварій при експлуатації джерел підвищеної небезпеки $(63,3$ \%) скоєно в сприятливій ситуації, значно менше $(27,5 \%)$ у нейтральній і тільки 9,2\% - в умовах перешкоджаючої ситуаціі. Поряд із цим конкретна ситуація в $63 \%$ випадків порушень правил безпеки давала особі достатню інформацію про можливість заподіяння шкоди, і у всіх випадках вона ж створювала для неї об'єктивну можливість уникнути шкоди. [2, С.47]

Зазначена закономірність $є$ свідченням того, що порушники за своїми особистими якостями в більшості своїй не відповідають ситуаціі, так як при усвідомленні небезпеки ситуації і наявної об'єктивної можливості уникнути заподіяння шкоди вони повинні були зробити це.

Особливо необхідно відмітити, що при порушенні правил безпеки джерело підвищеної небезпеки (обладнання, транспортний засіб) набуває самостійність. Використання його на шкоду суспільству не входить в сферу свідомої діяльності особистості. [3]

Отже, при порушенні правил безпеки небезпечна (криміногенна) ситуа- ція в їхньому генезисі практично завжди грає досить значиму роль.

Через встановлення кореляційних зв'язків між небезпечною (криміногенною) ситуацією та об'єктивною стороною злочинного порушення правил безпеки як зовнішнього вираження вчинення злочину, можна визначити характер взаємодії особистості (порушника), небезпечних властивостей ситуації та джерела підвищеної небезпеки.

Вплив небезпечної ситуації та властивостей джерела підвищеної небезпеки у кріміногенезі порушення правил безпеки, через класифікацію небезпечних ситуацій за рівнем складності, розроблену С.M. Іншаковим [4, С. 194], може бути представлений наступним чином:

1) Ситуація високого рівня складності - ситуація, з якою може впоратися і негативні наслідки якої здатний уникнути не всякий фахівець; забезпечення безпеки в такій ситуації - мистецтво.

Ситуація цього типу відіграє в генезі необережного злочину вирішальну роль.

2) Ситуація середнього рівня складності - забезпечення безпеки вимагає підготовки фахівця, вміння зібратися i сконцентруватися на прийнятті правильного рішення і подоланні небезпеки.

Роль ситуації цього типу і роль особистості в генезі необережного злочину рівнозначні.

3) Ситуація низького рівня складності - криміногенна ситуація відіграє другорядну роль у генезі злочину, головна роль належить негативним якостям особистості.

Проте слід враховувати, що навіть найбільш несприятлива ситуація не обов'язково призводить до скоєння злочину. Вирішальне значення, безумовно, належить конкретній людині з іï системою поглядів, схильностей і прагнень. Своєчасна нейтралізація небезпечного потенціалу ситуації і вжиття заходів до мінімізації ї шкідливої діі мають важливе значення для профілактики порушень правил безпеки.

Джерело підвищеної небезпеки та ситуація у випадку порушення правил безпеки мають підпорядковане зна- 
чення, яке може ускладнювати завдання особи щодо сприйняття їх впливів та ситуації загалом.

Отже, основні причини порушень правил безпеки обумовлені суперечностями між суб'єктом їх вчинення і об'єктивними обставинами (ситуацією, конкретними знаряддями праці, технічними засобами і т.п.). У той же час самі дефекти особистості порушника, небезпечні властивості ситуацій та знарядь криються в загально-соціальних причинах й умовах злочинності в цілому: політичній та економічній кризі, деформації суспільної та індивідуальної свідомості, дезорганізація суспільного життя.[5, C. 67]

Необхідно зазначити, що не кожна аварія або інші негативні наслідки на транспорті або виробництві $€$ результатом злочинного порушення правил безпеки, але науковими дослідженнями $[2 ; 6 ; 7]$ підтверджується той факт, що механізм порушення спеціальних правил безпеки, ї детермінанти, в основному, збігаються.

Ситуація i, наприклад, транспортний засіб як джерело підвищеної небезпеки виступають зовнішнім фоном, умовою вчинення злочину. Лише поведінкою суб'єкта (особистісний людський фактор), що взаємодіє із ситуацією і джерелом підвищеної небезпеки, загроза, що призводить до суспільно-небезпечних наслідків, реалізується в дійсності. Необхідно зазначити, що причини порушень правил безпеки кореняться в суперечності між двома цими сторонами, тобто полягають у невідповідності особистості (або іï поведінки) вимогам ситуації або стану технічного засобу.

Таким чином, об'єктивні чинники сприяють створенню кордону, меж, в рамках яких особа може вибрати як неправильний (необережний), так і правильний (тобто не порушує інтересів суспільства) варіант поведінки.

При розслідуванні будь-яких аварій 3 поля зору випадають причини психологічної складової поведінки безпосереднього учасника аварійної ситуації, який $€$ відповідальним за безпечне управ- ління об'єктом, адже, лише поведінкою суб'єкта (людський фактор), що взаємодіє із ситуацією і джерелом підвищеної небезпеки, загроза, що призводить до суспільно-небезпечних наслідків, реалізується в дійсності.

А. Ф. Зелінський вважав, що психологія необережних злочинів, які саме складають абсолютну більшість при порушенні правил безпеки, складається із діалектичного співвідношення помилок (дефектів) свідомості та неусвідомлюваних психічних процесів: «необережне спричинення шкоди відбувається через те, що свідомість винного «спрацювала» не так, як треба було б у цьому випадку, i iï місце у регуляції поведінки зайняли звички, установки, емоції» [8, с. 114].

Фактором, що впливає на оперативну надійність порушників правил безпеки, $€$ морально-вольові особливості їх особистості. Названий фактор займає центральне місце в системі детермінант делінквентної (злочинної) поведінки осіб, які порушують правила безпеки, так як саме він дозволяє зв'язати необережні дії цих осіб з сутністю вини, як негативним (недостатньо уважним) ставленням суб'єкта до виконуваних ним обов'язків.

Психофізіологічні стани суб'єкта відіграють істотну роль в його поведінці і нерідко є однією з причин виникнення аварійних ситуацій і серйозних аварій. Так, за даними отриманими в ході дослідження [2], 10,3% осіб спричинили аварію в результаті перевтоми; $2,6 \%$ - в результаті розгубленості в критичний момент; 25,7 \% - в результаті неуважності, поспішності, квапливості. Ще 1,5 \% перебували в момент аварії у хворобливому стані. Якщо до того ж врахувати осіб, які вчинили аварію у стані сп'яніння, яке помітно знижує велику кількість психофізіологічних функцій людини, то виявиться, що в третині випадків дефекти реакції грають вирішальну роль, можуть сприяти в складних умовах неправильному сприйняттю та оцінці ситуації, помилковому вибору варіанту поведінки, негативно позначиться на швидкості 


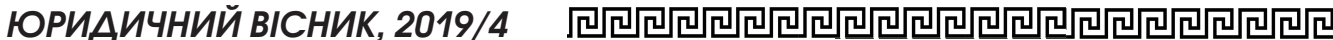

і точності вчинення дій, що тягне за собою тяжкі наслідки.

Взаємодія «небезпечної ситуації людського фактору - джерела підвищеної небезпеки» вимагає триєдиного вектору профілактичної діяльності через нейтралізацію небезпечного потенціалу ситуації, мінімізацію «людського фактору» та врахування небезпечних властивостей джерела підвищеної небезпеки, а саме:

1) нейтралізація небезпечного потенціалу ситуації: прогноз і припинення можливих варіантів надзвичайного ускладнення техногенної ситуації, що загрожує виходом техніки з-під контролю людей; вилучення із виробництва серійних технічних конструкцій, експлуатація яких створює такі ситуаціі; обмеження експериментальних ситуацій такого роду, забезпечення підвищеного рівня локалізації негативних наслідків під час технічних експериментів; поліпшення умов охорони праці, техніки безпеки;

2) мінімізація «людського фактору»: підвищення правової культури; підготовка фахівців та відпрацювання стандартів поведінки в небезпечних ситуаціях, постійне навчання, періодичне підвищення їх кваліфікації та поточний контроль за відповідністю рівня їх підготовки і психофізичного стану складності виконуваних завдань; виховна робота, спрямована на попередження тих чи інших порушень правил безпеки. Посилення відповідальності правопорушників цієї категорії.

3) джерело підвищеної небезпеки: нейтралізація небезпечних факторів, властивих технічним системам, і зменшення можливої шкоди від їх використання; чітка регламентація норм i правил безпеки; розроблення нових, максимально безпечних для людини і оточуючого середовища машин і механізмів; технічне удосконалення знарядь і засобів, підвищення їх надійності; контроль за технічним станом джерела підвищеної небезпеки.

Отже, до експлуатації джерел підвищеної небезпеки необхідно залучати не тільки залежно від компетенції та фізич- ного здоров'я, а й з урахуванням психофізіологічних показників та станів особистості та здійснювати подальший контроль цих показників у процесі використання/експлуатації джерела підвищеної небезпеки, наряду з своєчасною нейтралізацією небезпечного потенціалу ситуації та джерела підвищеної небезпеки і вжиття заходів до мінімізації іiі шкідливої дії.

Стаття присвячена визначенню основних засад профілактики злочинів, що вчиняються при порушенні правил безпеки. Зазначається, що не кожна аварія або інші негативні наслідки на транспорті або виробниитві є результатом злочинного порушення правил безпеки, але механізм порушення спеціальних правил безпеки, їх детермінанти, в основному, збігаються.

Ситуація $i$, наприклад, транспортний засіб як джерело підвищеної небезпеки виступають зовнішнім фоном, умовою вчинення злочину. Лище поведінкою суб'єкта (людський фактор), щзо взаємодіє із ситуацією $і$ джерелом підвищеної небезпеки, загроза, що призводить до суспільно-небезпечних наслідків, реалізується в дійсності. Необхідно зазначити, що причини порушень правил безпеки полягають у невідповідності особистості (або їі поведінки) вимогам cumуаціі або стану технічного засобу, тобто кореняться в суперечності між изими сторонами.

Таким чином, об'єктивні чинники сприяють створенню кордону, меж, в рамках яких особа може вибрати як неправильний (необережний), так $i$ правильний (тобто не порушуе інтересів суспільства) варіант поведінки.

Психологія порушення правил безпеки, складається із діалектичного співвідношення дефектів свідомості, що виражається в зневажливому ставленні до безпеки на транспорті або виробниитві, до життя $i$ здоров'я людей, ma психофізіологічних станів особистості. Зазначене дозволяе 
зв'язати необережні дї порушників з сутністю вини, як негативним (недостатньо уважним) ставленням суб’єкта до виконуваних ним обов'язків.

Взаємодія «небезпечної ситуаияї - людського фактору - джерела підвищеної небезпеки» вимагає триєдиного вектору профілактичної діяльності через нейтралізацію небезпечного потенціалу ситуації, мінімізацію «людського фактору» та врахування небезпечних властивостей джерела підвищеної небезпеки.

Ключові слова: джерело підвищеної небезпеки, небезпечний потенціал ситуації, людський фактор, порушення правил безпеки, злочинна необережність, психофізіологічні стани, профілактика.

Fedchun N. THE PREVENTION BASICS OF CRIMES, COMMITTED BY SAFETY RULES VIOLATION

The article is devoted to definition of the prevention basics of crimes, committed by safety rules violation. Noted that not every accident or other negative effects on transport or production are caused by criminal violation of safety rules, but the mechanism of violation of special safety rules and its determination are the same.

Defined that situation and source of hazard act as an external background, only by behavior of the subject (human factor), that interacts with situation and source of hazard, the threat, may be realized. The causes of safety rules violation lay in the inconsistency of the person (or his behavior) with the requirements of the situation or condition of technical means, i.e. lay in the antilogy of these sides.

In such a way, objective factors support the creation of borders, in the frames of which a person can choose as an incorrect (careless), so correct (that doesn't break common interests) variant of behavior.

Psychology of safety rules violation consists in dialectical relation of defects of consciousness (such as disrespectful attitude to safety on transport or production, to life and health of people) and psychophysiological states of the person. Mentioned accepts to connect careless actions of violators with the essence of the guilt, as with negative (not attentive enough) attitude to performed duties.

Interaction of "situation - human factor - source of hazard" requires a triple vector of prevention activity by neutralization of the dangerous potential of the situation, minimization of human factor and taking into account the hazardous properties of the high-risk source.

Key words: source of hazard, dangerous potential of the situation, human factor, safety rules violation, criminal negligence, psychophysiological states, prevention.

\section{Література}

1. Криминальная мотивация / цев и др.J ; под ред. В.Н. Кудрявиева. - М. : Наука, 1986. - $304 \mathrm{c}$.

2. Федчун Н.О. Кримінологічна безпека мореплавства та кримінально-правові засоби ї забезпечення: дис...канд.юрид. наук: спеи. 12.00.08 / H.О. Федчун. - О.: НУ «OЮA», 2014. - $241 \mathrm{c}$.

3. Дагель П.С. Неосторожность. Уголовно-правовые и криминологические проблемь. - М.: «Юрид. лит.», 1977. - 144 с.

4. Иншаков, С. М. Исследование преступности. Проблемы методики и методологии : монография / С. М. Иншаков. - М., 2012. $335 \mathrm{c}$.

5. Крайник Г. Мотиви злочинів, вчинених з необережності / Г. Крайник / / Юридична Україна. - 2014. - № 12. - С. 65-70.

6. Мисливий B. А. Злочини проти безпеки дорожнього руху та експлуатаиї транcпорту : [монографія] / В. А. Мисливий. Дніпропетровськ : Юридична академія МВС України, 2004. - $380 \mathrm{c}$.

7. Дришлюк И. А. Охрана безопасности движения и әксплуатации морского транспорта уголовно-правовыми средствами : автореф. дисс. ... канд. юрид. наук : спец. 12.00.08 / И. А. Дришлюк. - М., 1988. - 23 с.

8. Зелинский $A$. Ф. Осознаваемое и неосознаваемое в преступном поведении / А. Ф. Зелинский. - Х. : Вища школа, 1986. $168 \mathrm{C}$ 